\title{
Üçüncü Basamak Bir Hastanede Nokardiyoz Olguları ve İnfeksiyon Risk Faktörleri
}

\section{Nocardiosis Cases and Risk Factors for Infection in a Tertiary Care Hospital}

\author{
Seniha BAȘARAN(IDD), Ezgi YILMAZ(IDD), Serap șiMȘEK YAVUZ(İD), Atahan ÇAG̃ATAY(İD), Oral ÖNCÜL(İD), \\ Halit ÖZSÜT(IID), Haluk ERAKSOY(ID)
}

İstanbul Üniversitesi İstanbul Tıp Fakültesi Hastanesi, İnfeksiyon Hastalıkları ve Klinik Mikrobiyoloji Anabilim Dalı, İstanbul, Türkiye

Makale atıfı: Başaran S, Yılmaz E, Şimşek Yavuz S, Çağatay A, Öncül O, Özsüt H ve ark. Üçüncü basamak bir hastanede nokardiyoz olguları ve infeksiyon risk faktörleri. FLORA 2021;26(2):285-94.

\section{ÖZ}

Giriş: Nokardiyoz özellikle hücresel bağısıklı̆ı baskılayıcı tedaviler, diabetes mellitus, AIDS gibi bazı hastalıklar, bronşektazi ve kistik fibroz gibi anatomik bozukluklar, lenforetiküler maligniteler, solid organ kanserleri ve kemoterapi ile ilişkilendirilen ve en sık akciğer, beyin, göz ve deri tutulumu ile seyreden fırsatçı bir infeksiyondur. Bu çalışmada bir üçüncü basamak hastanesinde nokardiyoz hastaların klinik tabloları ve risk faktörleri sunuldu.

Materyal ve Metod: 2013-2019 yılları arasında hastanemizde izlenen ve herhangi bir klinik örneğinde Nocardia spp. üreyen ve bu etkene yönelik tedavi alan yetişkin hastalar retrospektif olarak değerlendirildi. Suşların tanımlanmasında klasik yöntemler, yapılabilenlerde tiplendirme için 16S rRNA veya MALDI TOF yöntemi, antimikrobiyal duyarlııkların belirlenmesinde gradient yöntemi kullanıldı.

Bulgular: Dokuz olgunun 4'ü disemine (tutulum görülen alanlar- akciğer, beyin, kas içi, göz), 4'ü akciğer, 1'i ise deri tutulumuyla seyretti. Hastaların 6's kortikosteroid, ikisi temozolomid, biri mikofenolat mofetil, biri ise siklofosfamid olmak üzere immunosupresif ilaç kullanmaktaydı. Bir hasta hariç tümü lenfopenikti. Tür düzeyinde tanımlanan 5 suş sırasıyla N. cyriacigeorgica (2 suş), N. farcinicia, N. asteroides ve N. abscessus ilk kez geçtikleri için açık yazılmaları gerekiyor. Nocardia cyriacigeorgica gibi) olarak adlandırıldı. Antibiyogram verisi olan 7 suşun tümü kotrimoksazole duyarlıydı.

Sonuç: Hücresel bağışıkı̆̆ı baskılanmış veya lenfopenik hastalarda gelişen, özellikle akciğer, merkezi sinir sistemi infeksiyonlarında etkenin Nocardia spp. olabileceği akla gelmeli. Akciğer nokardiyozu belirlenmiş kanser hastalarında MSS'de gelişen lezyonların ayırıcı tanısında MSS nokardiyozu da düşünülmelidir. Bugüne kadar nokardiyoz için tanımlanan birçok risk faktörünün arasında genel olarak kanser kemoterapileri yer alırken, derin lenfopeni yaratması nedeniyle temozolomid daha güçlü bir risk faktörü olarak karşımıza çıkmaktadır. Temozolomid alan hastalarda gelişen infeksiyon tablolarında nokardiyoz daha sık akla getirilip incelemeler yapılırsa gerçek nokardiyoz insidansının belirlenmesi ile gelecekte profilaksi stratejileri etkilenebilir.

Anahtar Kelimeler: Nocardia; Temozolomid; Risk faktörü

Geliș Tarihi/Received: 04/08/2020 - Kabul Ediliș Tarihi/Accepted: 10/12/2020

${ }^{\oplus}$ Telif Hakı 2021 Flora. Makale metnine www.floradergisi.org web adresinden ulașillabilir. 


\title{
ABSTRACT \\ Nocardiosis Cases and Risk Factors for Infection in a Tertiary Care Hospital
}

\author{
Seniha BAȘARAN, Ezgi YILMAZ, Serap șiMȘEK YAVUZ, Atahan ÇAG̃ATAY, Oral ÖNCÜL, Halit ÖZSÜT, \\ Haluk ERAKSOY
}

Department of Infectious Diseases and Clinical Microbiology, İstanbul University İstanbul Faculty of Medicine Hospital, İstanbul, Turkey

Introduction: Nocardiosis is an opportunistic infectious disease that involves the lungs, brain, eyes and skin and tends to occur in patients using immunosuppressive drugs (especially affecting cellular immunity) or chemotherapeutics, also in patients with diabetes mellitus, AIDS, lymphoreticular malignancies, solid cancers and architectural lung diseases such as bronchiectasis and cystic fibrosis. Here, it was aimed to present the clinical features and the risk factors of nocardiosis cases followed in a tertiary care hospital.

Materials and Methods: All adult patients with a culture-proven Nocardia spp. infection at our hospital from 2013 to 2019 were analyzed in the study retrospectively. Strains were identified by conventional methods and in the case of availability, by 16SrRNA gen analysis or MADI-TOF; antimicrobil susceptibilities were defined by gradient method.

Results: There were a total of 9 nocardiosis cases during the study period: 4 with disseminated (including pulmonary, brain, muscle, eye) nocardiosis, 4 with pulmonary nocardiosis and 1 case with skin nocardiosis. Corticosteroids, temozolomide, mycofenolate mofetil and cyclosoprin were used by patiensts as immunosupresive drugs in 6, 2,1 and 1 them, respectively. All of the patients were lymphopenic except one. Five strains identified at species level were N.cyriacigeorgica (2 strains), N.farcinicia, N.asteroides and N.abscessus, respectively. All of the 7 strains with available suceptibility test results were susceptible to co-trimoxazole.

Conclusion: Nocardia spp. should always be taken into consideration in the case of pulmonary or central nervous system infections of patients with supressed cellular immunity or lymphopenia. In the case of newly defined CNS lesion in a patient with both malignancy and pulmonary nocardiosis, CNS nocardiosis should always be kept in mind in the differential diagnosis. Although chemotherapeutic agents have always been defined as risk factors for nocardiosis, temozolomide could be a stronger risk factor because of its ability to cause a deeper lymphopenia. If nocardiosis is always to be considered in the case of a compatible clinical situation in patients on temozolomide regime, the real incidence of nocardiosis and prophylactic strategies among those patients could be defined properly.

Key Words: Nocardia; Temozolomide; Risk factors

\section{GiRiș}

Nokardiyalar; aerop aktinomiset grubundan, gram-pozitif, dallanan filamentöz yapıda, modifiye aside dirençli boyamalarla zayıf boyanan, cevre ortamda yaygın bulunan saprofit bakterilerdir. En sık deri, akciğer ve merkezi sinir sistemi tutulumuyla seyreden infeksiyonlara neden olur. Deri dıșındaki tutulumlarına sıklıkla bağısıklığı baskılanmıs konaklarda rastlanır ${ }^{[1]}$. Özellikle hücresel bağısıklı̆ğ baskılayıcı tedaviler (uzun süreli steroid tedavisi, solid organ nakillerinde kullanılan kalsinörin inhibitörleri, monoklonal antikorlar, inflamatuar barsak hastalı̆̆ı ya da romatolojik hastalıkların tedavisinde kullanilan TNF $\alpha$ blokerler), bazı hastalıklar (alkolizm, diabetes mellitus, AIDS, kronik granülomatöz hastalık) ve anatomik bozukluklar (kistik fibrozis, bronșektazi ve $\mathrm{KOAH}$ ) önemli risk faktörlerindendir ${ }^{[2-5]}$. Ayrica lenforetiküler maligniteler, solid organ kanserleri ve kemoterapi ile ilișkilendirilen nokardiyoz olguları da tanımlanmıș$\operatorname{tir}^{[6-8]}$. Bu çalıșmada, hastanemizde izlenen no- kardiyoz olgularının klinik ve laboratuvar özellikleri değerlendirilerek, ülkemizdeki nokardiyozlu hastalar hakkında veri sağlanması ve gözden kaçabilen bazı risk faktörlerinin vurgulanması amaçlanmıștır.

\section{MATERYAL ve METOD}

2013-2019 yılları arasında hastanemizde izlenen ve herhangi bir klinik örneğinde Nocardia spp. üreyen ve bu etkene yönelik tedavi alan yetisskin hastalar retrospektif olarak değerlendirildi. Hastane otomasyon sisteminden yas, cinsiyet, eșlik eden hastallklar, immünosüpresif tedaviler ve süreleri, bașvuru sikayeti ve taniya kadar geçen süre, total lökosit ve lenfosit sayısı, infeksiyonun bölgesi, toraks BT bulguları, kültürde değerlendirilen klinik örnek, etkenin türü, verilen antibiyotik tedavisi ve süresi, tedavi süresince mortalite bilgileri kaydedildi. Radyolojik olarak tutulumun görüldüğü bölgeden akciğer, beyin veya gözden ve deri/deri altı/kas içi lezyonlardan Nocardia spp. izole edilmesi ile aynı bölgenin nokardiyozu olarak 
tanımlandı. İki veya daha fazla bölge tutulumun görüldüğui durumlarda dissemine tutulum olarak değerlendirlidi. Kesin pulmoner nokardiyoz tanısı alan ve es zamanlı intrakranyal apseleri olan hastalarda tedaviyle intrakraniyal apselerin regresyonu olması halinde hasta es zamanlı olarak serebral nokardiyoz tanisı da aldı.

İnfeksiyon Hastalıkları ve Klinik Mikrobiyoloji birimince konsülte edilen ve firsatçı infeksiyonlardan kușkulanılarak bağıșıklığı baskılanmıș konaklardan alınmıs klinik örnekler Klinik Bakteriyoloji Laboratuvarında yedi gün inkübe edildi. \%5 koyun kanl1, cikolatamsı, MacConkey ve Sabouraud dekstroz agara ekilen örneklerden beyaz tebeșir atığı görünümlü koloni yapısında üremesi olanlar değerlendirildi. Gram yöntemiyle yapılan boyamada gram-pozitif, dallanan, uzun zincir yapan koloni yapısı olușturanlar ile modifiye Ehrlich Ziehl Neelsen (EZN) yöntemiyle zayif aside dirençli boyananlar Nocardia spp. olarak tanımlandi. Yapilabilenlerde ileri tiplendirme için $16 \mathrm{~S}$ rRNA veya MALDI TOF (MALDI Biotyper Systems, Bruker Daltonics, ABD) kullanıldı. Antimikrobiyal duyarlılıkların belirlenmesinde gradient yöntemi ${ }^{[9]}$ kullanıldı (E test, bioMérieux, Marcy-l Étoile, Fransa); duyarlılık sinırları CLSI'ya göre belirlendi ${ }^{[10]}$. Retrospektif çalısma olması nedeniyle ulașılabilen antibiyogram sonuçları değerlendirildi. Çalıșma için İstanbul Tip Fakültesi Etik Kurulundan onay alındı (Tarih: 08/05/2020, Karar No: 2020/569).

\section{BULGULAR}

Çalıșma süresince toplam dokuz nokardiyoz tanısı alan olguların üçü kadın, altısı erkekti. Yaș ortalaması 55 idi. Altı hasta bağıșıklığı baskılayıcı tedavi alırken, iki hastanın bağıșıklığı baskılayan hastalıkları (lenfoma, siroz), bir hastanın ise bronsektazisi vardi. Tüm immünosüpresyon rejimlerinde steroid bulunurken iki hastada temozolomid, birinde siklofosfamid bir diğerinde ise ek olarak mikofenolat mofetil vard. Bir hasta hariç tüm hastalar lenfopenikti $\left(<1500 / \mathrm{mm}^{3}\right)$.

Olguların dördü dissemine (tutulum görülen alanlar-akciğer, beyin, kas içi, göz), dördü akciğer, biri ise deri tutulumuyla seyretti.

Tüm örneklerde 48-96 saat icinde üreme saptand. Tür düzeyinde tanımlanan beș suș sırasıyla $N$. cyriacigeorgica (iki suș), $N$. farcinicia, $N$. asteroides ve $N$. abscessus olarak adlandirıldı.
Duyarlilık test sonucuna ulașılan yedi sușun hepsinde calıșılmıs olan kotrimoksazole, altı sușta ise karbapenemlere ve amikasine duyarliyd. Sușlarda test edilen antibiyotiklerin hiçbirine karșı direnç saptanmadi.

Böbrek yetmezliği olan bir hasta hariç tüm hastaların bașlangıc tedavisinde kotrimoksazol yer aldı. Bir hasta haric tüm hastalar bașlangıçta kombine tedavi aldılar. Bes hastanın kombinasyon tedavisinde meropenem, üc hastanın ise imipenem yer aldı. Kombinasyonda üçüncü en sık kullanılan antibiyotik amikasin (üc hasta) oldu. Yatıșının 15. gününde kaybedilen bir hasta ve kutanöz tutulumu olup sadece oral tedavi alan hastalar dișinda, diğer hastalar 4-6 haftalık parenteral antimikrobiyal tedaviyi takiben oral tedavileri planlanarak taburcu edildi. Akciğer adenokarsinomu nedeniyle taburculuğundan bir ay sonra ölen hasta dișında bes hastanın toplam tedavisi altı ay, iki hastanın bir yıla tamamlanması sağlandı. Tedavisi bir yıla uzatılan hastalardan biri göz ve akciğer tutulumu olan, diğeri ise temozolomid ve steroid tedavisine devam edilmek zorunda kalınan akciğer nokardiyozu olgusuydu. Serebral tutulumu olan bir hasta, farklı merkeze transferi nedeniyle takipten c1kt1. Hastaların klinik, radyolojik ve laboratuvar özellikleri Tablo 1'de, izole edilen sușların identifikasyon yöntemi ve duyarlılı sonuçları Tablo 2'de verildi.

\section{TARTIȘMA}

Günümüzde immünosüpresif tedavi alan hasta sayısındaki artıș, tanısal yöntemlerin gelișmesi ve kanserli hastaların sağ kalımının uzaması nokardiyoz insidansını artırmıștır ${ }^{[7,11]}$. U̇çüncü basamak hastanesi olan hastanemizde bağıșılı̆̆ı baskılayan tedavilerin yoğun kullanıldığı onkoloji, hematoloji, romatoloji gibi birimlerin bulunması nedeniyle son yıllarda nokardiyoz olgularıla daha sık karșılașıldı. Hastalarımızın cinsiyet dağılımına bakıldığında literatürdekine benzer bir sekilde \%67 oranla erkekler coğunluktaydı. Bakterinin çoğalması için hormonal bir yatkınlık olup olmadığı halen aydınlatılmamıs olmakla birlikte günümüzde de birçok seride erkek/kadın oranı yaklașık 2/1'dir ${ }^{[5,7,12,13]}$

Hastalarımızın risk faktörlerine bakıldığında nokardiyozda en iyi tanımlanmıș olan uzun süreli (en az bir ay) steroid kullanımı hastalarımızın 6/9'unda vardı ${ }^{[4]}$. Steroidin tetiklediŏi immünosüpresif mekanizması tam anlașlamamıssa da sitokin 


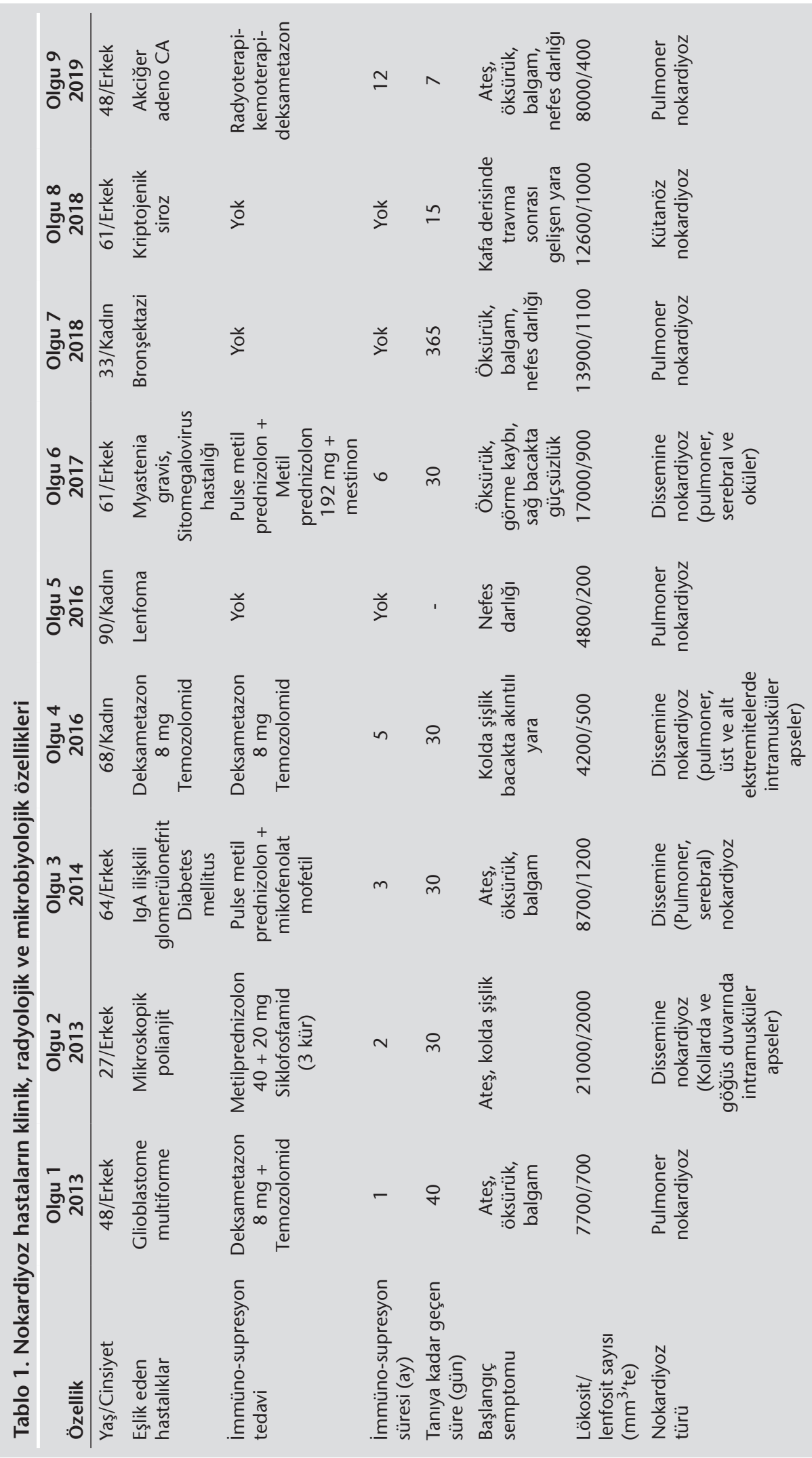




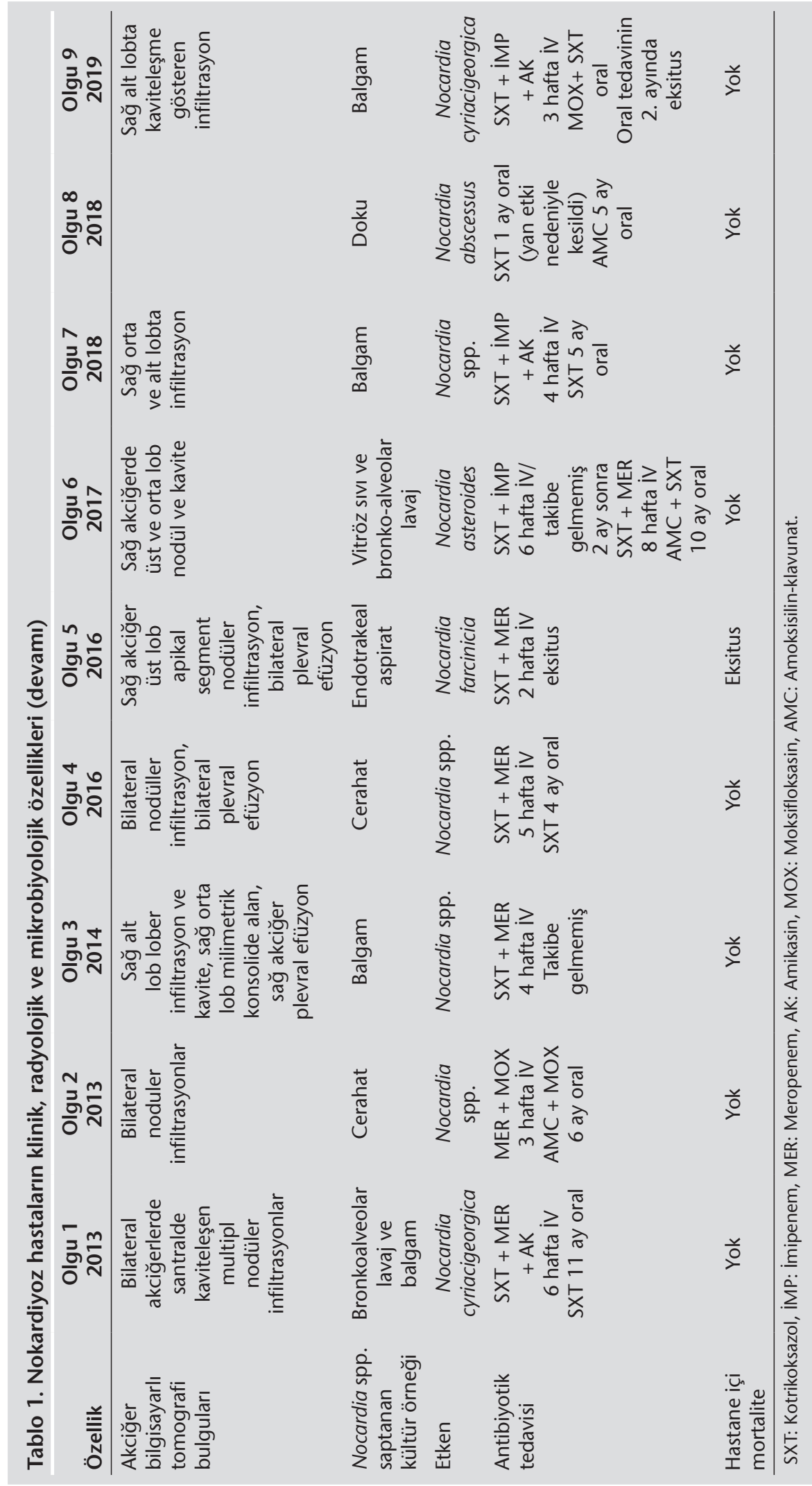




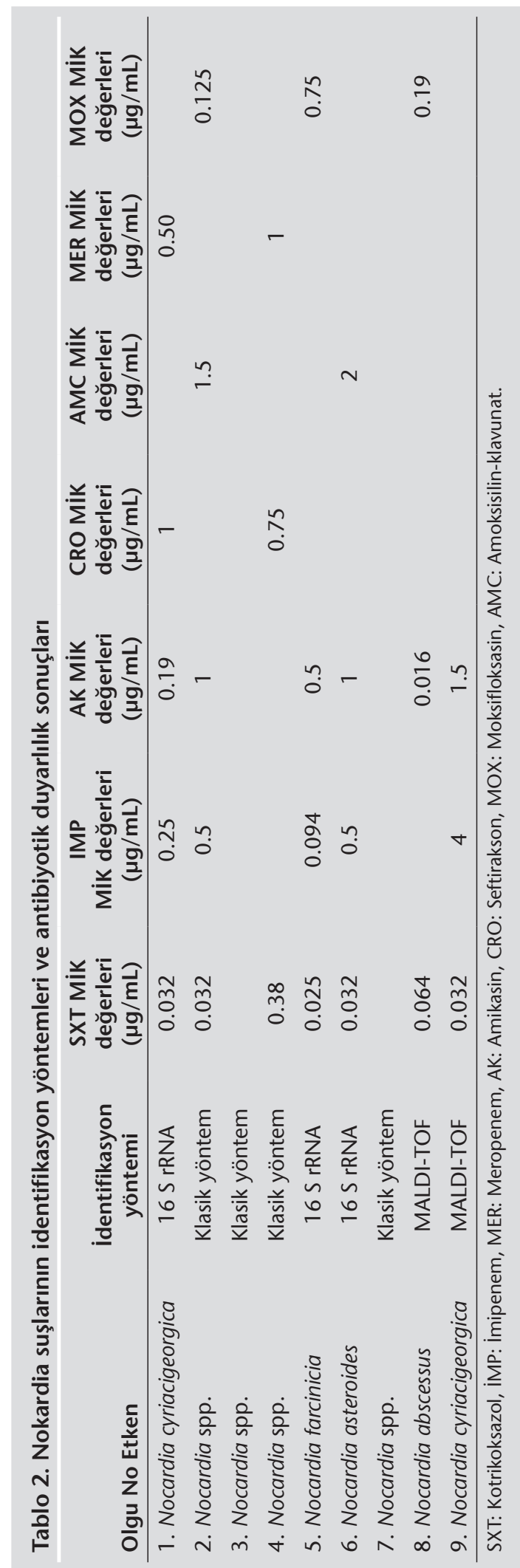

üretiminin inhibisyonu, olgun $\mathrm{T}$ lenfositlerin apoptozisinin indüklenmesi ve antijen sunan hücrelerin adezyonuna müdahale ettiği bilinmektedir ${ }^{[14]}$

Steroidin yanı sıra hastalarımızda kullanılan diğer immünosüpresif ajanlar iki glioblastoma multiforme tanilı hastada temozolomid, bir hastada siklofosfamid, bir hastada ise mikofenolat mofetildi. Literatürde glioblastoma multiforme nedeniyle temozolomid kullanımı ile ilgili bir hastada MSS nokardiyozu ve bir hastada dissemine nokardiyoz olmak üzere iki olgu bildirimi vardır ${ }^{[15,16]}$. Bizim takip ettiğimiz dokuz hastanın ikisinde glioblastoma nedeniyle temozolomid kullanımın olması dikkat cekiciydi. Hastanemizde yılda yaklașık 50 hastada GBM nedeniyle temozolomid kullanıldığı dikkate alındığında, yedi yılda temozolomid alan yaklaşık 350 hastanın ikisinde nokardiyoz gelişmesi, bu hasta grubunda nokardiyozun sıklığının yüksek olabileceğini düșündürmektedir. Temozolomidin lenfopeni ile ilișkisi birçok çalıșmada (üçüncü ayda hastaların \%60'inda $<800 / \mathrm{mm}^{3}$, steroid ve radyoterapi ile birlikte ise \%73'ünde tedavinin ikinci ayında CD4 sayısı $<300 / \mathrm{mm}^{3}$ ve tedavi sonrası 2 ay-1 yıl süreyle devam ettiği) gösterilmiștir ${ }^{[17,18]}$. Bir yıl içinde hastaların \%41'inde bir infeksiyon geliștiği görülmüs, ancak etiyolojik ajanlarla ilgili bilgi verilmemiștirir ${ }^{[18]}$. Bir bașka çalișmada temozolomidin PCP, CMV ve Aspergillus gibi ajanlarla ilișkisi gösterilmiștir ${ }^{[19]}$. Nokardiyoz eğilim yaratan durumların benzer olması nedeniyle temozolomid alan hastalarda nokardiyozun görülmesi saşırtıcı olmayacaktır ancak gercek insidansın saptanabilmesi için daha sık akla getirilmesi gerekmektedir.

Bir olgumuzda steroidle birlikte kullanılan siklofosfamidin, deneysel hayvan modellerinde daha cok B lenfositlerini etkileyerek lenfopeniye neden olup, Nocardia infeksiyonlarının gelișimini tetiklediği gösterilmiștir ${ }^{[20]}$. Otoimmün hastalığı olan nokardiyoz olgularının irdelendiği bir calısmada steroidin yanısıra en sik siklofosfamid kullanılan hastalarda lenfopeni saptandığı, bu olguların \%50'sinde belirgin lenfopeninin görüldüğü, lenfopenik olanların \%69'unda CD4+ T lenfositlerin ve neredeyse tamaminda $\mathrm{B}$ lenfositlerin belirgin sekilde düsưuk olduğu saptanmıștır. Bu calıșmada hipogamaglobulineminin olmaması nedeniyle B lenfositlerin infeksiyon üzerine etkisi irdelenmemis, 
daha çok $\mathrm{T}$ lenfositlerle ilişki kurulmustur ${ }^{[21]}$. Bir diğer olgumuzda kullanılmıș olan mikofenolat mofetil de özellikle lenfositlerde guanozin nükleotit sentezinde rol alan enzimin inhibisyonunu yaparak bașlica $\mathrm{T}$ lenfositler üzerinde sitotoksik etki göstermekte, bunun sonucunda ortaya cıkan immünosupresyon nedeniyle firsatçı etkenlerle infeksiyona eğilim yaratmaktadır ${ }^{[22]}$.

Akciğer kanseri ve beyin metastazları nedeniyle steroid ve radyoterapi (RT) almıs ve pulmoner nokardiyoz tanısı konulmus bir hastamız, antimikrobik tedavisinin ikinci ayında oral tedaviye geçilmesinden sonra kraniyal lezyonlarında progresyon olması nedeniyle kaybedildi. Temozolamid dahil immünosüpresif tedavi alan bir GBM hastasında ve metastatik akciğer kanseri olan bir hastada MSS'de ortaya cikan ve radyolojik incelemelerde yinelemeden veya metastazdan ayirt edilemeyen yeni lezyonların, yapilan biyospilerde nokardiyoz

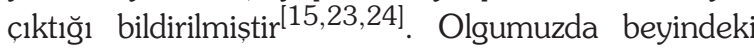
lezyonlardan biyopsi alınmadığı için bu tür bir durumun söz konusu olup olmadığı bilinmemektedir. Ancak bu tür hastalarda, beyin dokusundaki lokal hasarın yarattığı savunma kusurları, intrakranyal ödemin veya esas hastalığın tedavisi için verilen deksametazon veya temozolamid gibi immünosüpresifler ve nokardiyaların beyin dokusuna olan tropizmleri nedeniyle nokardiyal beyin apsesi gelișme riskinin yüksek olduğu akılda tutulmalıdır. Belirtilen özellikleri tașıyan hastalarda, özellikle pulmoner nokardiyoz da eșlik ediyorsa, MSS'de yeni gelisen lezyonlardan biyopsi alınarak nokardiyoz araștırılması tedavinin yönlendirilmesinde oldukça önemli bilgiler sağlayabilir.

İmmünosüpresif tedavi uygulanması dıșında bağıșkllı sistemini etkileyen bazı hastalıklar ve durumlarda da nokardiyoz sıklığı daha fazla olabilir. Birinde deri, birinde ise pulmoner nokardiyoz tanısı konulmus iki olgumuzda altta yatan, eğilim yaratan durum kriptojenik karaciğer sirozu ve yeni tanısı konulan lenfomayd. Siroz nedeniyle karaciğer transplantı alıcısı aday listesinde olan hastamızda, künt travma sonrasında kafa derisinde nokardiya apsesi gelișmiștir. Bağıșıklık sistemini etkileyen bu tür hastalığı olan kișilerde gelișen deri lezyonlarında nokardiyozun akılda tutulmas1 önemlidir. Toplum kökenli pnömoni nedeniyle yatıșı yapılıp, kan lenfosit sayısının cok düșük

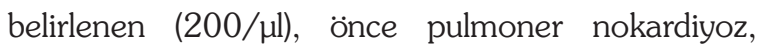
ardından lenfoma tanisı konulan hasta ise, toplumdan gelen ve derin lenfopenisi olan pnömonili hastalarda nokardiyanın ve bu infeksiyona eğilim yaratan durumların araștırılmasının, alınmıș kültür örneklerinin uzun süreli inkübasyonunun gerekliliğini hatırlatmaktadır.

Nokardiyoza sadece sistemik değil, yerel savunma sistemlerinde sorun olması da eğilim yaratabilir. Pulmoner nokardiyoz tanisı konulan bir hastamız bronșektazi nedeniyle takip edilmekteydi ve son bir yılda hastane yatıș ve parenteral antibiyoterapi gerektiren akut infektif atak sıklığında ciddi artıs gözlemlenmiști. Özellikle altta yatan kistik fibrozis veya bronșektazi gibi akciğer hastalığ olan bireylerde solunum yolunda nokardiya kolonizasyonu görülebilirr ${ }^{[1]} .12$ yılda 183 nokardiyoz hastasının incelendiği bir çalıșmada yıllar içerisinde brosektazili hastalarda Nocardia spp. insidansının arttığ1 saptanmıs, ancak retrospektif olan bu calıșmada kolonizasyon infeksiyon ayırımı yapılmamistır ${ }^{[25]}$. Bu hastalarda kolonizasyon infeksiyon ayırımı yapılırken akciğer görüntülemesinde pulmoner nokardiyozla uyumlu bulguların saptanması, gram boyamasında ya da modifiye aside direncli boyamayla bakterinin görülmesi, Nocardia spp.'nin kültürde saf olarak üretilmesi ya da tekrar eden kültür pozitifliğinin belirlenmesi önemlidir. Ancak bağıșkllğı baskılanmıs konaklarda solunum yolu örneklerinden nokardiya üretilmesi, hemen her zaman infeksiyon lehine değerlendirilmeli, klinik ya da radyolojik bir bulgu olmasa da asla göz ardı edilmemelidir ${ }^{[26]}$.

Nokardiyoz tanısı konulmus hastalarımızın biri haric hepsinde tanı anında lenfopeni mevcuttu. Pulmoner veya deri infeksiyonlariyla gelen lenfopenik hastalarda nokardiyozun ayırıcı tanıda yer alması önemlidir. Hastalarımızda lenfopeninin süresi bilinmemekle birlikte, immünosüpresif tedavi süresi en az bir aydi. Kortikosteroidlerin bir aydan uzun süre kullanımı, bir cok calısmada nokardiyoz için belirlenmis önemli risk faktörlerinden biridir ${ }^{[5]}$.

Olgularımızın 7/9'unda semptomların baslamasından tanı konulana kadar geçen süre bir aydan daha uzundu, hastaların hepsinindaha önce bașka merkezlere bașvurduğu, bu merkezlerde mikrobiyolojik inceleme için klinik örnek alınmadığı ve ampirik tedavilerle izlendiği görüldü. Literatürde de 
nokardiyozlu olguların tanısının ortalama bir ayda konulabildiği, hastaların öncesinde farklı tanılarla ampirik olarak tedavi edilmeye çalıșıldığı bildirilmektedir ${ }^{[12]}$. Tanı konulana kadar geçen sürenin bir ay olduğu yedi olgumuzun dördü dissemine olmuștu. İlk gören hekimin özel konak olan bu hastalarda kültuire dayalı bir yaklașım göstermiș olsaydı pulmoner tutulum așamasında bu hastaların tedavisi daha kolay ve prognozlarının daha iyi olması sağlanabilirdi. Nocardia spp. aerop bakterilerdir ve günlük kullanılan besiyerlerinde üreyebilirler, ancak üremeleri için 48-96 saat gerekmesi nedeniyle, kültür plaklarının bu sürelerde inkübe edilmediği durumlarda gözden kaçabilir. İnkübasyonun süresinin uzun tutulabilmesi, ancak klinisyenin ilgili laboratuvar ile ișbirliği yapması sonucu sağlanabilir. Bağıșıklığı baskılanmıș konaklarda, bașta pulmoner ve deri infeksiyonlarında olmak üzere ampirik tedaviler bașlanmadan önce uygun klinik örneklerin alınarak kültürünün yapılması ve kültür plaklarının en az 96 saat inkübe edilmesi nokardiyoz olgularının gözden kaçmasını engelleyecektir.

Vücuda giriș kapısının solunum yolu olması nedeniyle literatürle uyumlu sekilde hastalarımızın 7/9'unda pulmoner nokardiyoz vardi ${ }^{[26]}$. Hizel ve arkadașlarının 1974-2001 yılları arasında Türkiye'den bildirilen nokardiyoz olgularını derledikleri çalıșmada da pulmoner nokardiyozun (21/27) ilk sırada yer aldığı görüldï ${ }^{[27]}$. Hastalarımızda en sık belirlenen semptomlar öksürük ve balgam c1karma iken, bunları ates ve nefes darlığı izlemekteydi. U்lkemizden tek merkezden 16 nokardiyoz hastasının irdelendiği calıșmada pulmoner nokardiyoz tanısı alan 13 hastada da benzer semptom ve bulgular bildirilmistirr ${ }^{[28]}$. Olguların akciğer görüntülemelerinde en s1k nodüler lezyon (5/7), kavitasyon (5/7) ve plevral effüzyon (3/5) görülürken, 5/7'sinde tek taraflı tutulum belirlendi; en sık tutulan sağ akciğerdi. Bu konuda yapılan çalımalarda da benzer sekilde en sik infiltrasyon, nodüler lezyon, kavitasyon ve plevral efüzyon tanımlanmıs ${ }^{[13]}$, sağ akciğerin daha sık tutulduğu bildirilmiștir ${ }^{[5]}$.

Nokardiyozun yayılmasıyla gelișen metastatik odaklar arasında en sık MSS bildirilirken göz, yumușak doku, kemik-eklem tutulumları daha nadirdir ${ }^{[29]}$. Olgularımızn ikisinde MSS yayılımı varken, iki hastada intramusküler ve bir olguda oküler yayılım tanımlandı. Yumuşak doku tutulumu, bağı- sıklığ1 baskılanmıs konaklarda genellikle pulmoner tutulumun yayılımından kaynaklanmakla birlikte, bazen deriden giren mikroorganizmanin ilerlemesiyle de ortaya clkabilmektedir ${ }^{[30]}$. Bizim multiloküler kas içi apselerle seyreden iki olgumuzun da bağıșılklı̆ı baskılanmıstı, birinde pulmoner odak tanımlanırken, birinde tanımlanamadı. Pulmoner odak tanımlanamayan bu tür hastalarda pulmoner odak tutulumunun spontan remisyonu sonrası ortaya cıkan metastatik odakların aslında yanlıșlikla primer odak seklinde tanımlanabileceği de bildirilmektedir ${ }^{[29]}$.

İzole edilen Nocardia spp.'nin ikisi $N$. cyriacigeorgica, biri $N$. farcinica, biri $N$. asteroides ve biri de $N$. abscessus olarak tanımlandı. Ülkemizden klinik örneklerden izole edilen sușlarda tür düzeyinde tanımlanmanın yapıldığı 45 sus içeren bir seride (\%38'ini solunum yolu örneklerin olusturduğu) \%57 ile en sık $N$. cyriacigeorgica ${ }^{[31]}$, ikinci sırada $N$. farcinica saptanmıștır, ancak 9 sușun tanımlandığı bir diğer calıșmada ise 5 sus ile $N$. farcinica'nın ilk sırada yer aldığı görülmüștür ${ }^{[32]}$. Deri tutulumu ile seyreden bir olguda $N$. abscessus tanımlanmıs olup, bu tür ülkemizden yapılmış bir diğer çalıșmada da nokardiyoz etkenleri arasında tanımlanmıștır ${ }^{[31]}$. Literatuirde olduğu gibi ülkemizde de türlere göre değișen antibiyotik direnç oranları bildirilse de calıșmamızda duyarlılık testi yapilan yedi sușun hicbirinde test edilen antibiyotiklere karș1 direnc saptanmamıstır [31]

Nokardiyozda tedavinin ana bileșenlerinden biri sülfonamidlerdir. Serebral tutulumun olmadığı infeksiyonlarda ampirik tedavide amikasinin imipenem veya meropenemle ya da amikasinin TMP-SMX ile kombinasyonu uygun seçeneklerden bazlarıdır. Serebral nokardiyozun ampirik tedavisinde ise TMP-SMX ve meropenem ya da imipenem kombinasyonu uygun olabilir. Birçok nokardiyoz formunda bașlangıcta kombinasyon tedavisi tercih edilmeli ve antibiyotik duyarlılıkları sonuçlanana ve klinik yanit alınana kadar bu tedavi sürdürülmelidir ${ }^{[1]}$. Olgularımızın da biri dıșında hepsinde karbapenem, TMP/SXT ve amikasin içeren kombinasyon tedavileri uzun süreli kullanılmıștır. Nokardiyozla es zamanlı lenfoma tanısı alan bir hasta ve metastatik akciğer kanseri tanısı olan iki hasta tedavi sürecinde kaybedildi.

Sonuc olarak, özellikle hücresel bağıșıklığı baskılanmıș veya lenfopenik hastalarda gelișen, özellikle 
akciğer ve deri infeksiyonlarında etkenin Nocardia spp. olabileceği akla gelmeli, antimikrobik tedaviden önce kültür örnekleri alınarak, örnekler en az 96 saat inkübe edilmelidir. Akciğer nokardiyozu belirlenmiș kanser hastalarında MSS'de gelișen lezyonların ayırıcı tanısında MSS nokardiyozu da düșünülmelidir. Bugüne kadar nokardiyoz için tanımlanan birçok risk faktörünün arasında genel olarak kanser kemoterapileri de sayılmaktadır, ancak derin lenfopeni yaratan temozolomidin bu ajanlar arasinda bir risk faktörü olarak öne cıktığı görülmektedir. Temozolomid alan hastalarda gelișen infeksiyon tablolarında nokardiyozun da akla getirilmesi ve laboratuvarların bu konuda uyarılması ile bu ilaçla ilișkili gerçek nokardiyoz insidansının belirlenmesi gelecekte profilaksi stratejilerini etkileyebilir.

\section{TEŞEKKÜR}

Doç. Dr. Mert Ahmet Kușuucu'ya 16S rRNA analizinin yapılmasında verdiği destek için sonsuz teșekkürlerimizi sunarı.

\section{ETIK KURUL ONAYI}

Calıșma için İstanbul Tıp Fakültesi Etik Kurulundan onay alındı (Tarih: 08/05/2020, Karar No: 2020/569).

\section{ÇIKAR ÇATIŞMASI}

Yazarlar bu makale ile ilgili herhangi bir çkar çatıșması bildirmemișlerdir.

\section{YAZAR KATKISI}

Anafikir/Planlama: SȘY, SB

Analiz/Yorum: SB, EY

Veri sağlama: EY

Yazım: SB, SȘY

Gözden Geçirme ve Düzeltme: AÇ, OÖ, HÖ, $\mathrm{HE}$

Onaylama: Tüm yazarlar

\section{KAYNAKLAR}

1. Chen SC-A, Watts MR, Maddocks S, Sorrel TC. Nocardia species. In: Bennett JE, Dolin R, Blaser MJ (eds). Mandell, Douglas, and Bennett's Principles and Practice of Infectious Diseases. $9^{\text {th }}$ ed. PA: Elsevier, 2020:3059-70.

2. Peleg AY, Husain S, Qureshi ZA, Silveira FP, Sarumi M, Shutt $K A$, et al. Risk factors, clinical characteristics, and outcome of Nocardia infection in organ transplant recipients: a matched case-control study. Clin Infect Dis 2007;44(10):130714.
3. Ali T, Chakraburtty A, Mahmood S, Bronze MS. Risk of nocardial infections with anti-tumor necrosis factor therapy. Am J Med Sci 2013;346(2):166-8.

4. Martínez Tomás R, Menéndez Villanueva R, Reyes Calzada $S$, Santos Durantez M, Vallés Tarazona JM, Modesto Alapont $M$, et al.Pulmonary nocardiosis: risk factors and outcomes. Respirology 2007;12(3):394-400.

5. Ott SR, Meier N, Kolditz M, Bauer TT, Rohde G, Presterl E, et al; OPINION Study Group. Pulmonary nocardiosis in Western Europe-Clinical evaluation of 43 patients and population-based estimates of hospitalization rates. Int J Infect Dis 2019;81:140-8.

6. Torres HA, Reddy BT, Raad II, Tarrand J, Bodey GP, Hanna $H A$, et al. Nocardiosis in cancer patients. Medicine (Baltimore) 2002;81(5):388-97.

7. Wang HL, Seo YH, LaSala PR, Tarrand JJ, Han XY. Nocardiosis in 132 patients with cancer: microbiological and clinical analyses. Am J Clin Pathol 2014;142(4):513-23.

8. Ambrosioni J, Lew D, Garbino J. Nocardiosis: updated clinical review and experience at a tertiary center. Infection 2010;38(2):89-97.

9. Valdezate S, Garrido N, Carrasco G, Medina-Pascual MJ,Villalón P, Navarro AM, et al. Epidemiology and susceptibility to antimicrobial agents of the main Nocardia species in Spain. J Antimicrob Chemother 2017;72(3):754-61.

10. Woods GL, Brown-Elliott BA, Conville PS, Desmond EP, Hall $G S$, Lin $G$, et al. Susceptibility testing of mycobacteria, nocardiae, and other aerobic actinomycetes. 2nd ed, 31st vol. Clinical and Laboratory Standards Institute. Wayne, PA. 2011.

11. Tremblay J, Thibert L, Alarie I, Valiquette L, Pépin J. Nocardiosis in Quebec, Canada, 1988-2008. Clin Microbiol Infect 2011;17(5):690-6.

12. Matulionyte R, Rohner P, Uçkay I, Lew D, Garbino J. Secular trends of nocardia infection over 15 years in a tertiary care hospital. J Clin Pathol 2004;57(8):807-12.

13. Minero MV, Marín M, Cercenado E, Rabadán PM, Bouza E, Muñoz P. Nocardiosis at the turn of the century. Medicine (Baltimore). 2009;88(4):250-61.

14. Singh N, Rieder M, Tucker MJ. Mechanisms of glucocorticoid-mediated anti-inflammatory and immunosuppressive action. Paed Perinatal Drug Ther 2004;6(2):107-15.

15. Bertero L, Cassoni P, Rudà R. Nocardia abscesses mimicking tumor progression in gliomatosis cerebri responding to temozolomide. J Neurooncol 2015;121(1):225-7.

16. Poisnel E, Roseau JB, Landais C, Rodriguez-Nava $V$, Bussy E, Gaillard T. Nocardia veterana: disseminated infection with urinary tract infection. Braz I Infect Dis 2015;19(2):216-9.

17. Su YB, Sohn S, Krown SE, Livingston PO, Wolchok JD, Quinn $C$, et al. Selective CD4+ lymphopenia in melanoma patients treated with temozolomide: a toxicity with therapeutic implications. J Clin Oncol 2004;22(4):610-6. 
18. Grossman SA, Ye X, Lesser G, Sloan A, Carraway H, Desideri $S$, et al. Immunosuppression in patients with high-grade gliomas treated with radiation and temozolomide. Clin Cancer Res 2011;17(16):5473-80.

19. Stepanovic A, Nikitovic M. Severe hematologic temozolomide related toxicity and life threatening infections. I BUON. 2018;23(1):7-13.

20. Beaman BL, Maslan S. Effect of cyclophosphamide on experimental Nocardia asteroides infection in mice. Infect Immun 1977;16(3):995-1004.

21. Li S, Song XY, Zhao Yy, Xu K, Bi YL, Huang $H$, et al. Clinical analysis of pulmonary nocardiosis in patients with autoimmune disease. Medicine (Baltimore) 2015;94(39):e1561

22. Allison AC, Eugui EM. Mycophenolate mofetil and its mechanisms of action. Immunopharmacology 2000;47(23):85-118

23. Abel S, Hasan S, Kujawski B, Talwar A, Betler J, Wegner R, et al. Cryptic Nocardia nova brain abscess postradiation treatment and neurosurgery in a patient with small cell lung cancer: a case report and review of the literature. Adv Radiat Oncol 2016;1(4):290-3.

24. Voide C, Zimmermann S, Adjei AA, Betticher DC, Meuli R, Prod'hom $G$, et al. Cerebral nocardiosis mimicking multiple brainmetastases in a patient with locally advancednonsmall-cell lung cancer. J Thorac Oncol 2014;9(3):e24-6.

25. Woodworth MH, Saullo JL, Lantos PM, Cox GM, Stout JE. Increasing Nocardia incidence associated with bronchiectasis at a Tertiary Care Center. Ann Am Thorac Soc 2017;14(3):347-54
26. Wilson JW. Nocardiosis: Uptodates and clinical overview. Mayo Clin Proc 2012;87(4):403-7.

27. Hızel K, Çağlar K, Yılmaz F. Türkiye'de iç organ ve beyin tutulumuyla seyreden nokardiyoz olguları. Flora 2002;7(1):28-32.

28. Guliyeva G, Pullukçu H, Taşbakan MS, Metin DY, Sipahi OR, Yamazhan T, et al. Nokardiyoz: 16 hastanın değerlendirilmesi. Flora 2016;21(2):57-63.

29. Lerner PI. Nocardiosis. Clin Infect Dis 1996;22(6):891-903.

30. Lyos AT, Tuchler RE, Malpica A, Spira M. Primary soft-tissue nocardiosis. Ann Plast Surg 1995;34:212-4.

31. Uner MC, Hasçelik G, Müştak HK. Antimicrobial susceptibilities of clinical Nocardia isolates identified by $16 \mathrm{~S}$ rRNA gene sequence analysis. Mikrobiyol Bul 2016;50(1):11-20.

32. Yildiz O, Alp E, Tokgoz B, Tucer B, Aygen B, Sumerkan B, et al. Nocardiosis in a teaching hospital in the Central Anatolia region of Turkey: treatment and outcome. Clin Microbiol Infect 2005;11(6):495-9.

\section{Yazıșma Adresi/Address for Correspondence}

Uzm. Dr. Seniha BAȘARAN

İstanbul Üniversitesi İstanbul Tıp Fakültesi Hastanesi, İnfeksiyon Hastalıkları ve Klinik Mikrobiyoloji, İstanbul-Türkiye

E-posta: senihabasaran@yahoo.com 